Jurnal Ilmu Komunikasi, Penyuluhan dan Bimbingan Masyarakat Islam Vol. 3, No. 1, Januari 2020 P-ISSN: 2615-3181 E-ISSN: 2686-3227 Halaman $69-80$

\title{
STRATEGI KOMUNIKASI DAKWAH PENYULUH AGAMA NON PNS DALAM MEMBINA MASYARAKAT DESA BATU NYADI KECAMATAN KETUNGAU HILIR KABUPATEN SINTANG
}

\author{
Darmawan Saputra \\ Institut Agama Islam Sultan Muhammad Syafiuddin Sambas \\ Master93vid@gmail.com
}

\begin{abstract}
This study aims to find out the communication strategy of non-civil servant Religious Extension Workers in fostering rural communities which are formulated into three questions as follows: the role of Non-Civil Servant Religious Extension Workers in realizing rural communities. Diffusion of communication da'wah Non-civil servant Religious Extension in fostering rural communities and innovation of communication da'wah Non-civil servant Religious Extension in fostering rural communities in the district Ketungau Hilir Sintang district. The research method uses descriptive methods by making Non-Civil Servant Religious Extension of Sintang district that fosters rural communities as the main source in this research. This type of research is qualitative. The results showed that non-civil servant religious extension workers acted as agents of change by conducting persuasive-informative communication in resuscitating and fostering rural communities in ketungau hilir subdistrict of Sintang district. Diffusion of da'wah communication carried out by non-civil servant Religious Extension in fostering rural communities in the district ketungau Hilir Sintang district through activities in the form of ta'lim assembly and coaching da'wah cadres carried out at several points in the village of Beloh Mulyo, Indung Sepring, Mengaret and Batu Nyadi Village. Da'wah communication innovation carried out by non-civil servant religious extension workers in the form of implementation of da'wah cadreization program in the village through training activities and ta'lim assembly.
\end{abstract}

Keywords: Communication Strategy, Non-Civil Servant Religious Extension, Coaching, Rural Communities

\begin{abstract}
ABSTRAK
Penelitian ini bertujuan untuk mengetahui strategi komunikasi dakwah Penyuluh Agama Non PNS dalam membina masyarakat pedesaan yang dirumuskan menjadi tiga pertanyaan sebagai berikut: peran Penyuluh Agama Non PNS dalam menyadarkan masyarakat pedesaan. Difusi komunikasi dakwah Penyuluh Agama Non PNS dalam membina masyarakat pedesaan dan inovasi komunikasi dakwah Penyuluh Agama Non PNS dalam membina masyarakat pedesaan di kecamatan Ketungau Hilir kabupaten Sintang. Metode penelitian menggunakan metode deskriptif dengan menjadikan Penyuluh Agama Non PNS kabupaten Sintang yang membina masyarakat pedesaan sebagai sumber utama dalam penelitian ini. Jenis penelitian adalah
\end{abstract}


kualitatif. Hasil penelitian menunjukkan bahwa Penyuluh Agama Non PNS berperan sebagai agen perubah dengan melakukan komunikasi persuasif-informatif dalam menyadarkan dan membina masyarakat pedesaan di kecamatan Ketungau Hilir kabupaten Sintang. Difusi komunikasi dakwah yang dilakukan oleh Penyuluh Agama Non PNS dalam membina masyarakat pedesaan di kecamatan Ketungau Hilir kabupaten Sintang melalui kegiatan berupa majelis ta'lim dan pembinaan kader dakwah yang dilaksanakan di beberapa titik di anataranya Desa Beloh Mulyo, Indung Sepring, Mengaret dan Desa Batu Nyadi. Inovasi komunikasi dakwah yang dilakukan oleh Penyuluh Agama Non PNS berupa penyelenggaraan program kaderisasi dakwah masuk Desa melalui kegiatan pelatihan dan majelis taklim.

Kata Kunci : Strategi Komunikasi, Penyuluh Agama Non PNS, Pembinaan, Masyarakat Pedesaan

\section{PENDAHULUAN}

Dewasa ini Agama Islam, adalah Agama yang keadaannya semakin terpojokkan dan paling banyak di teror dari berbagai sisi. Akan tetapi suatu saat kelak Allah Akan Mengangkat dan memuliakan Agama Islam serta mencapai kejayaan sehingga menguasai penjuru dunia. perlu diketahui ternyata Islam memiliki umat terbanyak di Dunia, dan ini menunjukkan bahwa besar pula sumber daya manusianya serta generasinya, dan tentunya satu-satunya Agama yang paling di cintai dan diridhoi Allah Ta'ala. Sehingga semakin memperkuat keyakinan Ummat Islam untuk senantiasa Istiqomah menjalankan Agama ini dengan baik dan benar. Namun sangat disayangkan, Umat ini terpecah belah.

Mulai dari berbedanya pemahaman serta aqidah, berbeda negara, berbeda daerah serta ketidak cocokan dalam menjalankan Agama ini, ditambah dengan berbagai aliran yang tersebar luas, serta mazhab dan golongan. maraknya organisasi-organisasi yang mengatas namakan Islam yang menjadikannya sibuk dengan perbedaan sehingga mudah dikalahkan oleh musuhnya. Ummat yang harusnya menjadi contoh, memiliki kepribadian yang kuat, mampu menciptakan segala yang dibutuhkan, serta menjadi pemebri solusi segala problematika kehidupan dunia dan Akhirat. Ternyata menjadi ummat yang tamak akan harta dan jabatan, ditimpa kesusahan dan kekurangan, serta merosotnya akhlak dan keimanannya kepada Allah Ta'ala. Melihat keadaan dan kondisi serta kenyataan seperti ini, maka merupakan perkara yang sangat penting strategi dan bekal berdakwah di pedalaman kalimantan barat. Dengan mengajarkan perkara-perkara yang mendasar dengan penuh semangat serta tanpa mengharap imbalan apapun kecuali hanya mengharap pahala dari Allah Ta'ala. Sebagaimana Firmannya :

"Katakanlah (Muhammad),"Aku tidak meminta imbalan sedikitpun kepadamu atasnya (dakwahku), dan aku bukanlah termasuk orang yang mengada-ngada". (Qs. Sad(38) : 86

Dan Allah Berfirman :

"Karena itu, serulah (mereka beriman) dan tetaplah (beriman dan berdakwah) sebagaimana diperintahkan kepadamu (Muhammad) dan janganlah mengikuti keinginan mereka dan katakanlah, "Aku beriman kepada Kitab yang diturunkan Allah dan Aku dierintahkan agar berlaku adil di antara kamu. Allah Tuhan kami dan Tuhan Kamu. Tidak perlu ada pertengkaran 
antara kami dan kamu, Allah mengumpulkan antara kita dan kepada-Nyalah kita kembali." (Qs. Asy-Syura (42) : 15).

Akan tetapi seiring dengan berjalannya perkembangan zaman baik ilmu pengetahuan dan tekhnologi diikuti berbagai sarana komunikasi dan informasi yang sangat cepat menjadikan sebagian umat manusia khususnya masyarakat pedesaan dalam hal ini desa Batu Nyadi kecamatan ketungau hilir. mengalami pergeseran norma-norma Agama serta mulai kehilangan jati diri sebagai ummat yang mengaku beriman kepada sang Kholiq. Disebabkan oleh maraknya budaya barat di tengah-tengah masyarakat hingga masuk ke pedesaan melalui media masa sebagai trend dan malah di jadikan kebiasaan. Hal tersebut dapat dilihat dari beberapa kasus dimana laki-laki dan perempuan berboncengan secara bebas, kumpul kebo, serta cara atau model berpakaian wanita di pedesaan sudah tidak memperhatikan dan mengabaikan perintah Allah bahwa wanita wajib menutup auratnya. Yang lebih parahnya berpenampilan serba ketat dan kelihatan aurat serta lekuk tubuhnya.

Selain itu antusias masyarakat pedesaan mengikuti majelis taklim serta sholat berjamaah ke masjid semakin berkurang bahkan tinggal takmirnya saja, karena kesibukan dunia dan disibukkan dengan gajet dan Televisi, dan juga kondisi anak-anak zaman sekaran seiring perkembangan zaman lebih suka memandang $\mathrm{Hp}$, internet dan Televisi daripada hadir ke musholla untuk mengaji dan sholat berjama'ah serta masuk pesantren. Melihat Fenomena diatas juga ditemukan di kecamatan Ketungau Hilir kabupaten Sintang Kalimantan Barat yang mayoritas masyarakatnya di pedesaan. Masyarakat pedesaan yang berada di kecamatan Ketungau Hilir kabupaten Sintang lebih cenderung mengikuti gaya hidup orang-orang kafir yang datangnya dari dunia barat. diantara penyebabnya adalah gencarnya informasi yang didapatkan melalui jaringan media massa dan internet. Selain itu masyarakat pedesaan di kecamatan Ketungau Hilir kabupaten Sintang juga dalam pengamalan norma-norma semakin hari semakin menurun .

Hal ini dapat disaksikan masyarakat menghadiri kegiatan-kegiatan seperti majelis ta'lim, membaca Al-Qur'an, dan sholat berjama'ah. Disisi lain, para pemuda dan anak-anak yang nanti diharapkan menjadi generasi penerus estafet dakwah sesuai yang di ajarakan Rasulullah Sholallahu Alaihi Wasalam (Observasi : 10-01-2021)

Kenyataan ini tentunya sangat menjadi perhatian khusus bagi para da'i untuk menggerakan dakwah Islam pada masyarakat pedesaan melalui majelis taklim dan kaderisasi dakwah sehinggan melahirkan generasi yang taat menjalankan Agama ini.

Dengan berpegang teguh kepada aqidah Islam seluruh masyarakat beserta remaja dan anak-anknya bisa mengembalikan ruh keislamannya sehingga taat beribadah kepada Allah Ta'ala.

Dengan demikian, tujuan dakwah pada masyarakat pedesaan bisa merubah pola hidup yang religius serta kebiasaan mengikuti gaya barat semakin terkikis dengan senantiasa mengamalkan Al-u'an dan Sunnah dan semata-mata mencontoh Baginda Sholallahu Alaihi Wasalam serta semakin memperkokoh dan mempertebal keimanannya. 
Agar tujuan dakwah dapat tercapai dengan baik, maka dakwah harus dilakukan dengan cara pendekatan yang baik, strategi, metode serta teratur dan terarah.

Pendekatan adalah sudut pandang terhadap suatu masalah, pendekatan merujuk kepada pandangan tentang terjadinya suatu proses yang sifatnya masih umum. Strategi adalah rencana strategi untuk mencapai sesuatu. Metode adalah cara untuk mencapai sesuatu. Teknik adalah cara yang lebih khusus dalam penerapan suatu metode sedangkan taktik adalah cara seseorang dalam melaksanakan suatu teknik atau metode. (Aziz: 2016, 208)

Maka, sebelum memulai dakwah hendahnya seorang pendakwah atau da'i harus menguasai dan memahami kondisi masyarakat dan medan dakwah yang akan di jadikan sebagai ladang dakwah. Baru kemudian, menyusun rencana serta jadwal dakwah yang akan dilaksanakan dengan merancang startegi khusus sesuai dengan kondisi masyarakat dan medan dakwah. Dengan mengembangkan cara dakwah seperti tersebut di atas, maka harapannya memberikan perubahan yang positif pada setia individu masyarakat, remaja dan anak-anak.

Oleh karenanya merupakan target dakwah adalah adanya perubahan akhlaq dan sikap pada masyarakat yang menjadi objek dakwah Islam.

Dalam prakteknya, dakwah tidak mesti melalui ceramah, khotbah dan pengajian. Akan tetapi dengan, adanya seorang da'i memberikan sikap serta akhlaq yang baik maka ini juga merupakan dakwah. Sejak tahun 2015 Penyuluh Agama Islam Non PNS yang diselenggarakan oleh kementrian Agama Kabupaten Sintang, telah memulai pembinaan masyarakat pedesaan Batu Nyadi Kecamatan Ketungau Hilir Kabupaten Sintang.

Penelitian ini didasari kondisi masyarakat Desa Batu Nyadi Kecamatan Ketungau Hilir masih sangat jauh dari norma dan nilai agama, baik sholat berjama'ah dan menghadiri pengajian dll.

Sehingga hadirnya Da'i Penyuluh Agama Islam Non PNS sangat dirasakan manfaatnya oleh masyarakat Desa Batu Nyadi Kecamatan Ketungau Hilir Kabupaten Sintang. Meskipun pada hakekatnya Masyarakat Desa Batu Nyadi Kecamatan Ketungau Hilir memiliki karakteristik yang berbeda-beda. Baik dari segi budaya, ekonomi, tingkatan Pendidikan, serta pemahaman tentang ajaran Agama Islam yang dampaknya sangat berpengaruh terhadap dakwah yang disampaikan. Sehingga Penyuluh Agama Islam non PNS merancang strategi komunikasi dakwah yang relevan agara maksud dan tujuan dakwah yang di sampaikan melalui majelis taklim serta pembinaan kaderisasi para pemuda dapat tersalurkan dengan baik.

Oleh karenanya, penelitian ini bertujuan untuk mengetahui strategi komunikasi dakwah Penyuluh Agama Islam non PNS di masyarakat Desa Batu Nyadi Kecamatan Ketungau Hilir Kabupaten Sintang yang dirumuskan dalam beberapa pertanyaan. Pertama, bagaimana peran Penyuluh Agama Islam non PNS dalam menyadarkan masyarakat pedesaan di Desa Batu Nyadi Kecamatan Ketungau Hilir. Kedua, bagaimana difusi komunikasi dakwah Penyuluh Agama Islam non PNS dalam membina masyarakat Desa Batu Nyadi Kecamatan Ketungau Hilir. Ketiga, bagaimana inovasi komunikasi dakwah Penyuluh Agama Islam non PNS dalam membina masyarakat Desa Batu Nyadi Kecamatan Ketungau Hilir. 
Penelitian ini menggunakan motode deskriptif. Metode deskriptif bertujuan melukiskan secara sistematis fakta atau karakteristik populasi tertentu atau bidang tertentu secara faktual dan cermat. Penelitian deskriptif hanyalah memaparkan situasi atau peristiwa, tidak mencari atau menjelaskan hubungan, tidak menguji hipotesis atau membuat prediksi. Data yang dikumpulkan adalah berupa kata-kata, gambar, dan bukan angka-angka. Penelitian terdahulu pernah dilakukan terkait strategi komunikasi dakwah dalam pembinaan mental narapidani (Ariyanto, Firosyurahman, Mangkarto, Barkah \& Fatoni, 2019).

Strategi komunikasi Lembaga Pemasyarakatan dalam pembinaan mental warga binaan masyarakat Desa Batu Nyadi Kecamatan Ketungau Hilir menggunakan strategi ceramah, khutbah serta majelis Ta'lim Al-Hikmah. Penelitian tentang strategi komunikasi dakwah berbasis multikultural (Marfu'ah, 2017).

Hasil penelitian menunjukkan bahwa strategi komunikasi dakwah yang digunakan dalam masyarakat yang multikultural dengan cara pendekatan multikulturalisme dalam dakwah, yakni berusaha untuk mencapai dua hal, yaitu titik temu dalam keragaman, dan toleransi dalam perbedaan. Penelitian tentang strategi komunikasi dakwah dengan mengambil penelusuran terhadap cara berdakwah Walisanga (Tajuddin, 2014).

Penelitian merujuk pada konsep, pola, metode dan model dakwah Rosulullah Saw dalam menyampaikan risalah ajaran Agama Islam. Salah satu kunci kesuksesan dakwah Rosulullah Saw adalah penggunaan komunikasi interpersonal yang tepat dan efektif terhadap madh'u-nya. Penelitian tentang strategi komunikai dakwah Salaf (Rumakat, 2017). Hasil penelitian menunjukkan bahwa salah satu kesuksesan strategi komunikasi dakwah kaum salaf adalah merujuk pada cara dakwah Rosulullah Saw. Salah satunya melalui cara atau metode nabi Muhammad Saw dalam menyampaikan risalah Islam.

Adapun penelitian berkaitan dengan aspek pembinaan masyarakat yang menjadi acuan diantaranya, penelitian tentang pembinaan masyarakat melalui pondok pesntren (Muslimin, yohanes \& Supriadi, 2013). Penelitian ini terfokus pada peran pondok pesantren dalam melakukan pembinaan dan pemberdayaan masyarakat di Desa Desa Batu Nyadi Kecamatan Ketungau Hilir.

Berdasar latar belakang di atas, maka penelitian ini bertujuan untuk mengetahui peran Penyuluh Agama Islam non PNS dalam menyadarkan masyarakat, proses difusi informasi dan inovasi dalam membina masyarakat Desa Batu Nyadi Kecamatan Ketungau Hilir Kabupaten Sintang.

\section{HASIL DAN PEMBAHASAN}

Strategi komunikasi adalah paduan perencanaan komunikasi (communication planning) dengan manajemen komunikasi (communication management) untuk mencapai tujuan yang telah ditetapkan. Untuk mencapai tujuan tersebut strategi tersebut harus mampu menunjukkan bagaimana operasionalnya secara praktis harus dilakukan. Dalam arti kata bahwa pendekatan (approach) bisa berbeda sewaktu-waktu tergantung pada situasi dan 
kondisi. Jadi dengan demikian strategi komunikasi adalah keseluruhan perencanaan, taktik, cara yang akan dipergunakan guna melancarkan komunikasi dengan memperhatikan keseluruhan aspek yang ada pada proses komunikasi untuk mencapai tujuan yang diinginkan (Permana, 2013: 124).

Strategi komunikasi dapat diartikan sebagai strategi yang memberikan kerangka kerja yang berisi kombinasi aktifitas komunikasi yang dapat menyebabkan perubahan dalam pengetahuan, pendapat, sikap, kepercayaan atau tingkah laku dari komunitas target yang penting untuk memecahkan masalah dalam suatu jangka waktu tertentu dan menggunakan sumber daya tertentu pula (Azizah, 2010: 81).

Dakwah merupakan upaya tutur tindak yang dibalut dengan pesan-pesan ilahiah sebagai pesan utama, Kesuksesan dakwah sebagai kegiatan berkomunikasi yang menitikberatkan pada transformasi perilaku beragama di dalam masyarakat, tidak bisa terpisah dari aspek bahasa. Agama Islam mengajarkan bahasa universal dalam berdakwah seperti yang termaktub di dalam kitab suci Al Qur'an. Karakteristik Bahasa dakwah seperti yang diajarkan di dalam Al Qur'an adalah menyampaikan yang baik sehingga ajaran tersebut dapat masuk kedalam hati pendengar (Kholidah, 2014: 1).

Keterampilan dalam komunikasi perlu dikuasai oleh seorang penyampai pesan (da'i) supaya mampu memastikan makna yang disampaikan dapat difahami oleh pendengar. Dengan kata lain, keperluan memahami psikologi tentang motivasi, tingkah laku dan rangsangan terhadap sasaran akan membantu kelancaran mempengaruhi madh'u (Ahmad Fauzi \& Aini, 2017: 82).

Strategi komunikasi dakwah merupakan sebuah perencanaan yang efektif dan sistematis dari komunikator (da'i) untuk merubah perilaku komunikan (masyarakat) sesuai dengan ajaran Islam. Dalam hubungannya dengan dakwah Islam, strategi komunikasi dakwah merupakan kepiawaian seorang da'i dalam menangani sesuatu, terkait metode dan pendekatan yang digunakan untuk meraih sesuatu, serta memiliki watak dasar identifikatif, dan bukan apologistik.

Salah satu teori yang penting dalam memahami proses strategi komunikasi dakwah adalah teori difusi inovasi. Difusi adalah proses dimana inovasi dikomunikasikan melalui saluran-saluran tertentu pada suatu jangka waktu tertentu, diantara anggota sistem sosial (Rogers;1995:5-6) Pesan yang disebarluaskan dalam proses komunikasi tersebut berisi ideide, atau praktik yang bersifat baru atau dianggap baru. Difusi merupakan medium inovasi yang digunakan agent of change ketika berupaya membujuk seseorang agar mengadopsi suatu inovasi. Sehingga dapat disebut, difusi adalah tipe khusus dari komunikasi yang berisi pesan tentang ide baru.

Ada 4 tahapan dalam proses difusi inovasi ( Rogers;1995:10), yaitu: inovasi, media komunikasi, waktu dan sistem sosial. Inovasi adalah ide, praktik atau objek yang dianggap sebagai sesuatu yang baru oleh individu atau kelompok yang mengadopsinya. Kebaruan suatu inovasi tak tergantung pada pengertian yang benar-benar baru secara objektif, namun jika suatu ide tampak baru bagi seseorang maka hal tersebut adalah inovasi. 
Seseorang dapat mengetahui tentang inovasi beberapa saat sebelumnya, namun ia belum menentukan sikap, tidak mendukungnya, tidak mengadopsinya atau menolaknya. Ini artinya, inovasi tidak dibatasi hanya pada pengetahuan yang benar-benar baru bagi seseorang. Everett M Rogers memberikan asumsi bahwa sedikitnya ada 4 tahap dalam suatu proses adopsi inovasi, yaitu Pengetahuan, Persuasi, Keputusan dan konfirmasi. Masyarakat Desa Batu Nyadi Kecamatan Ketungau Hilir kabupaten Sintang umumnya menganut agama Islam serta memiliki nilai adat yang masih kental.

Hal ini sangat terlihat apalagi dalam ruang lingkup masyarakat pedesaan, khususnya masyarakat Desa Batu Nyadi Kecamatan Ketungau Hilir kabupaten Sintang. Masyarakat di daerah ini rata-rata bekerja sebagai petani karet dan kelapa Sawit yang tingkat pendidikannya masih rendah. Penghasilan serta pekerjaan mereka sebagai petani belum mampu meningkatkan kesejahteraan hidup mereka dengan baik.

Disamping itu masyarakat Desa Batu Nyadi Kecamatan Ketungau Hilir kabupaten Sintang ini dalam hal pengamalan ajaran agama Islam masih jauh. Tahun 2006 banyak masyarakat Desa Batu Nyadi Kecamatan Ketungau Hilir kabupaten Sintang masuk islam. Akan tetapi satu demi satu murtad atau keluar dari Agama Islam disebabkan tidak adanya bimbingan dan pengajaran Agama terhadap mereka (Wawancara : 19.30)

Hal ini juga lebih disebabkan tidak adanya atau kurangnya seorang da'i yang mampu mengajari, menyampaikan dan membina masyarakat di desa tersebut. Lokasi yang jauh, kondisi jalan rusak dan berlumpur serta medan dakwah yang sangat sulit menjadi alasan seorang da'i untuk terjun mendampingi,memberikan pengajaran dan memberikan pencerahan kepada masyarakat. Sehingga masyarakat yang berada di Desa Batu Nyadi Kecamatan Ketungau Hilir kabupaten Sintang tidak dapat melaksanakan kegiatan ibadah dengan bimbingan yang benar, serta tidak mendapatkan informasi tentang pesan-pesan agama Islam secara komprehensif.

Namun setelah diadakannya pembinaan yang dilakukan oleh Penyuluh Agama Islam Non PNS kehidupan keagamaan masyarakat Desa Batu Nyadi Kecamatan Ketungau Hilir kabupaten Sintang berkembang lebih baik.

Tentu hal ini tidak akan terlepas dari apa yang disebut dengan proses yang dilalui dengan tahapan-tahapan yang bertujuan untuk menyadarkan masyarakat di pedesaan. Tahapan-tahapan yang ada dalam kegiatan pembinaan yang dilakukan oleh Penyuluh Agama Islam Non PNS menjadi landasan awal untuk menentukan strategi yang mampu mengantarkan masyarakat cara beragama dengan baik dan benar. Tahapan-tahapan yang dilakukan dalam kegiatan pembinaan tersebut antara lain:

Pertama, permasalahan. Merupakan suatu objek tertentu yang diyakini oleh da'i (agen perubah) yang akan menjadi jawaban dari sebuah permasalahan yang ada. Disini yang menjadi permasalahan adalah masyarakat Desa Batu Nyadi Kecamatan Ketungau Hilir kabupaten Sintang itu sendiri yang secara umum masih tertinggal terutama pengetahuan tetantang ajaran Agama Islam. Sehingga kegiatan pembinaan disini dianggap sebagai pemecah permasalahan yang ada pada masyarakat Desa Batu Nyadi Kecamatan Ketungau Hilir kabupaten Sintang. 
Kedua, Sumber perubah. Individu, organisasi, kelompok yang berusaha untuk membawa perubahan masyarakat melalui kegiatan pembinaan. Dalam kegiatan pembinaan ini yang menjadi sumber perubah adalah Penyuluh Agama Islam Non PNS sendiri yakni Bapak H. Darius Saputra, pejabat pemerintah daerah setempat dalam hal ini Kementrian Agama Kabupaten Sintang yang telah melakukan kerjasama untuk bersama-sama memajukan masyarakat pedesaan.

Ketiga, media atau saluran. Komunikasi dan distribusi dijadikan sebagai media, dimana pengaruh dan respon nantinya akan merubah masyarakat. Media yang digunakan dalam pembinaan dan proses pengajaran keagamaan kepada masyarakat Desa Batu Nyadi Kecamatan Ketungau Hilir kabupaten Sintang bukanlah media elektronik dan media massa pada umumnya.

Namun media yang digunakan adalah dengan komunikasi interpersonal yang berupa perbincangan dalam sebuah forum yang berbentuk majelis ta'lim, penyuluhan, dan pelatihan. Dimana dalam kegiatan ini menjadi media antara da'i dan masyarakat bersama-sama membahas tentang problematika kehidupan yang ada terutama yang berkaitan dengan Agama Islam.

\section{Difusi komunikasi dakwah Penyuluh Agama Islam Non PNS}

Difusi merupakan sebuah proses bagaimana suatu inovasi dikomunikasikan lewat channel (media) tertentu sepanjang waktu kepada anggota kelompok dari suatu sistem sosial. "Diffusion is the process by which an innovation is communicated through certain channels over time among the members of a social system." Sesuai dengan pemikiran Rogers, dalam proses difusi terdapat 4 (empat) elemen pokok, yaitu: inovasi, saluran komunikasi, jangka waktu, dan sistem social.

Diantara bentuk difusi komunikasi dakwah yang telah dilakukan oleh Penyuluh Agama Islam Non PNS dalam proses pembinaan masyarakat pedesaan antar lain: 1). Majelis ta'lim 2). Kaderisasi Dakwah yang terdiri dari para Remaja. Kedua program ini kemudian menjadi kegiatan yang rutin dilaksanakan oleh Penyuluh Agama Islam Non PNS sebagai media menyampaikan pesan-pesan dakwah untuk mewujudkan masyarakat yang Religius.

Majelis ta'lim merupakan salah satu difusi komunikasi dakwah Penyuluh Agama Islam Non PNS yang dilakukan kepada masyarakat Desa Batu Nyadi Kecamatan Ketungau Hilir kabupaten Sintang. yang dilaksanan setiap pekan sekali dan setiap bulan sekali di masjid desa yang ada diantaranya Masjid Al-Hikmah, Masjid Beloh Mulyo, Masjid Indung Sepring dan Surau Mengaret.

Rasa semangat yang tinggi mengikuti kegiatan majelis ta'lim ini, mereka menyimak dan memperhatikan setiap untaian kalimat yang disampaikan oleh Penyuluh Agama Islam Non PNS dalam hal ini Bapak H. Darius Saputa kepada mereka. Hal ini dibuktikan dengan jumlah masyarakat yang hadir ke majelis ta'lim semakin hari semakin bertambah sebagai bukti bahwa komunikasi yang dilakukan Penyuluh Agama Islam Non PNS dapat dikatakan sebagai komunikasi yang efektif. 
Selain menyasar masyarakat yang terdiri dari ibu-ibu dan bapak-bapak, Penyuluh Agama Islam Non PNS juga menjadikan anak-anak dan remaja sebagai sasaran penerima difusi komunikasi dakwah mereka. Diantaranya kaderisasi dakwah yang siap diterjunkan kedesadesa untuk menyampaikan pesan-pesan dalam ajaran Agama Islam.

Secara umum penerapan kegiatan pembinaan masyarakat pedesaan yang dilakukan dengan membentuk kegiatan mejelis ta'lim dan kaderisasi dakwah untuk para Remaja. Hal ini disebabkan karena pemberdayaan baik manusia bukan dilihat hanya berdasarkan pembangunan semangat dalam diri masyakat Desa Batu Nyadi Kecamatan Ketungau Hilir kabupaten Sintang. Namun lebih dari itu, kegiatan pemberdayaan manusia melaui kegiatankegiatan tersebut diatas langsung dirasakan oleh masyarakat.

Difusi komunikasi dakwah berupa pesan-pesan dakwah yang disampaikan oleh Penyuluh Agama Islam Non PNS dalam membina masyarakat Desa Batu Nyadi Kecamatan Ketungau Hilir kabupaten Sintang terdiri dari beberapa kategori yakni; Pertama, pesan Tauhid. Pesan Tauhid merupakan pesan pertama dan utama yang disampaikan oleh Penyuluh Agama Islam Non PNS dalam melakukan pembinaan kepada masyarakat. Pesan Tauhid ini disampaikan melalui majelis ta'lim yang diselenggarakan setiap sebulan sekali. Bentuk dari pesan Tauhid itu meliputi keimanan kepada Allah, malaikat, nabi dan rasul, kitab-kitab, hari kiamat dan taqdir baik dan buruk yang terkumpul dalam rukun iman yang enam.

Kedua, pesan aqidah. Setelah pesan aTauhid tersampaikan, pesan selanjutnya yang disampaikan kepada masyarakat Desa Batu Nyadi Kecamatan Ketungau Hilir kabupaten Sintang adalah pesan aqidah. Pesan aqidah ini dititik beratkan pada pemahaman beraqidah dengan baik danbenar sesuai yang diajarkan oleh Rasulullah Sholallahu Alaihi Wasalam.

Ketiga, pesan akhlakul karimah. Rumusan pesan akhlakul karimah menjadi salah satu pesan yang disampaikan oleh Penyuluh Agama Islam Non PNS dalam membina masyarakat Desa Batu Nyadi Kecamatan Ketungau Hilir kabupaten Sintang. Pesan akhlakul karimah merupakan pesan yang berisi tentang bagaimana seseorang berinterasksi dan besosialisasi antar sesama, dengan lingkungan, dengan Robbnya sesuai dengan apa yang dicontohkan oleh Nabi Muhammad Sholallahu Alaihi Wasalam.

\section{Inovasi komunikasi dakwah Penyuluh Agama Islam Non PNS}

Inovasi merupakan sebuah gagasan atau ide, tindakan atau suatu produk yang dianggap baru oleh orang lain. Dalam penelitian ini yang dimaksud inovasi adalah gagasan dan tindakan yang dilakukan oleh Penyuluh Agama Islam Non PNS dalam membina masyarakat Desa Batu Nyadi Kecamatan Ketungau Hilir kabupaten Sintang.

Sejak tahun 2006 sebagai prioritas pembinaan masyarakat. Hal ini dilakukan untuk membentengi aqidah masyarakat pedesaan dari ajaran-ajaran agama lain yang datang untuk mengajak masyarakat meyakini agama mereka. Inovasi komunikasi dakwah yang dilakukan oleh Penyuluh Agama Islam Non PNS yakni terwujudnya kehidupan masyarakat Desa Batu Nyadi Kecamatan Ketungau Hilir kabupaten Sintang secara Religius, baik religius dalam pola pikir, pola hidup dan menjadi percontohan bagi desa lain dalam tatanan kehidupan masyarakat yang Religius. 
Dalam tahap ini seseorang belum mengetahui informasi mengenai sebuah inovasi baru tersebut. Untuk itu informasi mengenai inovasi tersebut harus disampaikan melalui media massa, media elektronik maupun komunikasi interpersonal di antara mereka. Pertama, pengetahuan. Pada tahapan pengetahuan dalam pembinaan masyarakat Desa Batu Nyadi Kecamatan Ketungau Hilir kabupaten Sintang ini adalah menyampaikan dan menginformasikan pesan-pesan dakwah dalam upaya menyadarkan masyarakat untuk meningkatkan taraf hidup masyarakat tersebut. Pada tahap pemberian informasi atau pengetahuan ini, maka peran seorang da'i sangat dibutuhkan oleh masyarakat yang akan menerima pesan-pesan dakwah.

Setelah masyarakat mau untuk menerima perubahan yang disampaikan dan dibawa oleh da'i melalui pertimbangan yang matang, maka selanjutnya masyarakat tersebut dapat mengikuti kegiatan yang telah diberikan oleh Penyuluh Agama Islam Non PNS. Pertimbangan untuk menerima inovasi yang disampaikan oleh da'i kepada masyarakat di Desa Batu Nyadi Kecamatan Ketungau Hilir kabupaten Sintang merupakan pertimbangan yang mampu menhatasi problematika masyarakat yang sekian lama belum ada orang yang siap membina mereka.

Maka ketika Penyuluh Agama Islam Non PNS hadir di tengah-tengah mereka, mereka memilih untuk menerima inovasi pembinaan da'i tersebut. Butuh proses dan waktu yang lama untuk menumbuhkan atau menyadarkan masyarakat. Baru kemudian setelah masyarakat menerima akan perubahan yang disampaikan oleh para da'i, kemudian membuat program yang tujuannya adalah untuk memahamkan kepada masyarakat tentang ajaran agama Islam, sehingga terwujudnya tatanan kehidupan masyarakat yang religius sesuai dengan cita-cita Islam itu sendiri.

Masyarakat yang sudah mengetahui pesan tentang adanya sebuah kegiatan pengajian, sebagian dari mereka menerima dan mengikuti kegiatan tersebut. Akan tetapi hanya beberapa kali saja, setelah itu mereka berhenti dan tidak pernah datang untuk mengikuti pengajian. Sehingga strategi lagi untuk meyakinkan masyarakat dan membujuk masyarakat untuk menerima dan mengikuti kegiatan pengajian yang dilaksanakan setiap sebulan sekali. Begitu pula dengan remaja, mereka harus diberikan hadiah atau iming agar mau mengikuti kegiatan kaderisasi dakwah.

\section{PENUTUP}

Pembinaan masyarakat yang merupakan salah satu objek dakwah tidak akan terlepas dari yang namanya strategi komunikasi. Ia merupakan satu kesatuan yang saling melengkapi satu sama lain. Sejak awal masyarakat Desa Batu Nyadi Kecamatan Ketungau Hilir kabupaten Sintang merupakan masyarakat dengan penganut agama Islam, namun masih banyak masyarakat yang belum memahami tentang Islam.

Hal ini disebabkan karena masuknya budaya baru yang mempengaruhi gaya kehidupan masyarakat dan kurangnya pembimbing agama yang senantiasa membimbing masyarakat untuk mengamalkan nilai-nilai ajaran Islam. Sebagai seorang da'i, termasuk Penyuluh Agama Islam Non PNS harus mencari cara agar penyampaian pesan-pesan dakwah dengan tujuan 
akhir mengubah sikap dan perilaku masyarakat agar dapat mengamalkan nilai-nilai ajaran Islam dapat tersampaikan dengan baik dan diterima oleh masyarakat.

Dari sekian banyak pembahasan yang sudah dipaparkan, dapat ditarik kesimpulan sebagai berikut: Pertama, Peran Penyuluh Agama Islam Non PNS dalam menyadarkan masyarakat pedesaan melalui komunikasi persuasif dan informatif. Kedua, Difusi komunikasi dakwah yang dilakukan oleh Penyuluh Agama Islam Non PNS dalam proses pembinaan masyarakat pedesaan telah menarik perhatian banyak masyarakat untuk mengikuti dan mengamalkan pesan-pesan dakwah yang mereka dapatkan. Melalui kegiatan majelis ta'lim, kaderisasi Remaja untuk berdakwah. Ketiga, Inovasi komunikasi dakwah yang disampaikan oleh Penyuluh Agama Islam Non PNS kepada masyarakat pedesaan merupakan inovasi yang sangat dibutuhkan oleh masyarakat Desa Batu Nyadi Kecamatan Ketungau Hilir kabupaten Sintang. Keberhasilan dakwah melalui kegiatan pembinaan masyarakat pedesaan yang dilakukan oleh Penyuluh Agama Islam Non PNS disebabkan penentuan strategi komunikasi dakwah yang relevan dan sesuai dengan kebutuhan masyarakat. Oleh karenya perlu kiranya saran serta masukan disampaikan dalam rangka perbaikan serta penyempurnaan untuk keberhasilan kegiatan dakwah kedepannya, baik untuk Penyuluh Agama Islam Non PNS sendiri maupun bagi yang lainnya.

Dalam memulai kegiatan dakwah hendaknya para da'i dan para Penyuluh Agama Islam Non PNS menggunakan strategi pendekatan yang dapat membuat masyarakat tertarik untuk mengikuti ajakan tersebut. dengan membangun kepercayaan dikalangan masyarakat, memberikan solusi dalam mengatasi tumpang tindih permasalahan yang dihadapi oleh masyarakat. 


\section{DAFTAR PUSTAKA}

AD, Y. (2017). Pembinaan Masyarakat Islam Melalui Pendekatan Dzikir dan Pikir Studi Pada Majlis Ta'lim Ar-Rahman RT 17 Desa Way Huwi Kecamatan Jatiagung Lampung Selatan. Jurnal Konseli, 4(2). Ahmad Fauzi, N.U., \& Aini, Z. (2017). Strategi Pemujukan dalam Komunikasi Dakwah Masyarakat Orang Asli. Jurnal Fikiran Masyarakat, 5(2).

Ariyanto, B., Firosyurahman, M., Mangkarto, M.R.K., \& Fatoni, U. (2019). Strategi Komunikasi Dakwah dalam Pembinaan Mental Narapidana. Jurnal Sahafa Journal of Islamic Communication, 1(2).

Azizah, S. (2010). Strategi Komunikasi Pembinaan Pembudidayaan Kambing Boer untuk Meningkatkan Taraf Ekonomi Masyarakat di Desa Wonosari, Kecamatan Wonosari, Kabupaten Malang, Provinsi Jawa Timur. Jurnal Ilmu Komunikasi, 7(1).

Aziz, Ali M. (2009). Ilmu Dakwah, Jakarta: Prenada Media Group. Kholidah, L.N. (2014). Kontekstualisasi Bahasa Qur'ani Dalam Komunikasi Dakwah: Strategi Tindak Tutur Transformasi Pesan- Pesan Keagamaan. Jurnal Bahasa dan Seni, 42(1),.

Marfu'ah, U. (2017). Strategi Komunikasi Dakwah Berbasis Multikultural. Jurnal Islamic Communication Journal, 2(2).

Muslimin, Yohanes, B., \& Supriadi. (2013). Partisipasi Pondok Pesantren Darussalam Sengkubang Pembinaan Pendidikan Agama Pada Masyarakat Desa Sengkubang. Jurnal Pendidikan dan Pembelajaran, 2(9).

Munib, A. (2017). Peranan Pondok Pesantren Azzubir Dalam Pembinaan Akhlaq Masyarakat Desa Talesah Kecamatan Tlanakan Kabupaten Pamekasan. Jurnal Al-Ulum: Jurnal Penelitian dan Pemikiran Islam, 4(1).

Nursaleh, N., Baihaqie, E., \& Kosasih, A. (2013). Pemanfaatan ProgramProgram Multimedia Religius Sebagai Sarana Pembinaan Keagamaan Masyarakat Desa Keresek Dan Padasuka Kecamatan Cibatu Kabupaten Garut. Jurnal Dharmakarya, 2(1).

Permana, R. (2013). Strategi Komunikasi Dakwah Band Wali dalam Lagu Cari Berkah. Jurnal Komunikasi Islam, 3(1).

Rahmat, J. (2002). Metode Penelitian Komunikasi, Bandung : Remaja Rosda Karya.

Rumakat, M.T. (2017). Strategi Komunikasi Dakwah Kaum Salaf. Jurnal Peurawi, 1(1).

Sakdiah, H. (2017). Komunikasi Interpersonal sebagai Strategi Dakwah Rasulullah (Perspektif Psikologi). Alhadharah: Jurnal Ilmu Dakwah, 15(30).

Sudarman, A. (2018). Strategi Komunikasi untuk Meningkatkan Kesadaran Masyarakat dalam Membayar Zakat Maal, dalam Jurnal Communicatus: Jurnal Ilmu Komunikasi, 2(1).

Tajudiin, Y. (2014). Walisongo dalam Strategi Komunikasi Dakwah, dalam Jurnal Addin, 8(2). 